\title{
Pelaksanaan Jaring Aspirasi Sebagai Komunikasi Publik Pemerintah Daerah Kabupaten Kulon Progo
}

\author{
Bawa Supratman ${ }^{1}$, Fatah Nashir ${ }^{2 *}$, A.S. Rahman ${ }^{3}$, Zainul Arifin ${ }^{4}$, Cipto Sembodo ${ }^{5}$ \\ ${ }^{1}$ Badan Kesatuan Bangsa dan Politik Kabupaten Kulonprogo, ${ }^{2}$ Badan Permusyawaratan \\ Desa Petanahan Kabupaten Kebumen, ${ }^{3,4,5}$ Universitas Cokroaminoto Yogyakarta \\ *Penulis Koresponden, email: fatahnashir@gmail.com
}

\begin{abstract}
Abstrak
Jaring aspirasi yang dikenal juga dengan Kamispaginan telah menjadi menjadi penghubung formal warga dengan pemimpin pemerintah daerah Kabupaten Kulonprogo. Dengan cara bertemu muka dengan bupati secara langsung di setiap hari kamis diharapkan informasi masyarakat segera terserap untuk mendapatkan permasalahan secepatnya. kajian sosiologi hukum ini dimaksudkan untuk mendapatkan bagaimana prosesnya berjalan. maka penelitian dilakukan dengan cara observasi, dokumentasi dan wawancara. Triangulasi juga dilakukan untuk mendapatkan validitas data sesuai harapan. Analisis kualititatif bersifat deskriptif analitis terhadap hasil data terkumpul. Informasi dan aduan masyarakat dalam kamispaginan diselesaikan dalam empat kategori tergantung dengan kualitas informasinya. Pola demikian memuaskan warga masyarakat dan menyadarkan bahwa informasi tidak selalu bisa diselesaikan dalam satu kesempatan terutama dalam persoalan yang memerlukan kordinasi dengan kelembagaan lainnya. Kamispaginan menjadi perwujudan salah satu bentuk musyawarah bersama antara pimpinan derah dan masyarakatnya yang patut untuk dilanjutkan dengan peningkatan sosialisasi agar partisipasi masyarakat juga bertambah.

Kata kunci: Jaring Aspirasi, informasi publik, komunikasi, pemerintah daerah
\end{abstract}

\begin{abstract}
Jaring Aspirasi is a liaison between the people and the local government leaders of Kulonprogo Regency. With the face-to-face model with a regent every Thursday, it is hoped that publik information will be absorbed immediately to solve problems as soon as possible. This legal sociology study is intended to find out how the process works. then the research was conducted by means of observation, documentation and interviews. Triangulation was also carried out to obtain data validity as expected. Qualitative analysis is analytical descriptive of the results of the collected data. The information and publik complaints in the seminar department are resolved in four categories depending on the quality of the information. This pattern satisfies members of the community and makes them realize that information cannot always be resolved at one time, especially in matters requiring disposition with other institutions. Kamispaginan as a form of publik service is a form of joint deliberation between the regional government
\end{abstract}

This is an open access article under the (C-BY-SA license @c) (1) () 
and the community which should be continued with increased socialization so that community participation will also increase.

Keywords: Jaring Aspirasi, publik information, comunication, local government

\section{Pendahuluan}

Penjaringan aspirasi masyarakat dewasa ini telah beragam bentuk. Informasi publik di dalamnya merupakan informasi-informasi yang perlu disampaikan kepada masyarakat oleh pemerintah dalam batas tertentu atau sebaliknya. Teknologi informasi yang cepat telah memberikan kemudahan dalam penyampaian dan penerimaan informasi publik, sebagian institusi pemerintah pun telah mengandalkannya dalam jaring aspirasi tersebut termasuk memecahkan permasalahan administrasi publik yang dialami oleh masyarakat dan penggunanya.(Sitoresmi 2013; Triantaka dan Griadhi 2015)

Namun sebagian institusi pemerintah masih yakin bahwa komunikasi secara fisik, tatap muka, masih menjadi sarana penting dalam komunikasi publik, terutama di level terendah pemerintahan, yaitu tingkat desa/kelurahan (Anomsari 2013; Atmadja 2017), ataupun saat pemilihan umum (Zana 2014). Sementara jaring aspirasi melalui Kamispaginan (selanjutnya disingkat menjadi Kpg) berbeda karena penghubung pemda dengan warganya.

Jaring aspirasi melalui komunikasi langsung pimpinan pemerintah yang didampingi oleh aparat jajaran pemerintah daerah Kabupaten Kulonprogo dan rakyatnya itu dalam pelaksanaannya dikenal dengan banyak nama. Sebagian besar masyarakat lebih suka menyebutnya sebagai Kpg karena kemudahan sekaligus pengingat hari pelaksanaannya (Nashir 2017). Pertemuan memang diadakan setiap hari Kamis pagi di pendopo rumah dinas Bupati Kulonprogo. Di dalamnya adalah silaturahim dan komunikasi bersifat vertikal antara Bupati dengan rakyatnya maupun pihak yang lainnya. Kegiatan ini dimulai beriringan dengan masa pemerintahan Bupati Hasto Wardoyo di Kabupaten Kulonprogo pada tahun 2011 hingga berakhirnya masa jabatannya. 


\section{Metode Penelitian}

Penelitian empiris ini menggunakan sosiologi hukum sebagai pendekatan. Dalam pengumpulan data digunakan observasi pengamatan dan dokumen selain wawancara. Pengamatan dilakukan pada saat Kpg dilaksanakan di Pendopo Kabupaten di setiap hari Kamis pagi di periode tertentu. Dokumentasi yang dominan adalah laporan pelaksanaan yang diarsipkan oleh staf PPID Kabupaten sekaligus organisator pelaksananya. Dalam wawancara, Sebagai informan diprioritaskan kepada penggagas Kpg di Kabupaten Kulonprogo, yaitu bapak Bupati Kulonprogo periode 20112016. Data primer itu ditunjang dengan informasi yang diperoleh dari hasil wawancara dengan para staf PPID dan beberapa warga selaku peserta. Triangulasi dilakukan dengan perpanjangan waktu dan perbandingan data terkumpul dari masing-masing instrument. Analisa kualitatif akan mengantarkan pada penarikan kesimpulan secara deduktif induktif.

\section{Kamispaginan, Pemerintah Daerah dan informasi Publik}

Maksud dari Kamispaginan adalah proses komunikasi dengan cara tatap muka antara bupati dengan rakyatnya. Selama berjalan terjadi penerimaan aduan dari warga masyarakat dan pemberian masukan bagi warga yang terlibat dalam pelaksanaan akitivitas publik di Kabupaten Kulonprogo. Keluhan yang dihadapi oleh masyarakat yang berkaitan langsung dengan pemerintah maupun tidak. Permasalahan yang diajukan, diharapkan memperoleh solusinya. Dalam mencari solusi pemerintah mempertimbangkan terlebih dahulu. Apabila mendapat solusi secara langsung dengan cara musyawarah.

Sesuai dengan yang didapatkan dari pemerintahan Kulonprogo bahwa tujuan diselenggarakan kegiatan kamis paginan rakyat beragama.(PPID Kabupaten Kulonporogo 2014, 2015) Penyerapan partisipasi publik dibutuhkan dalam pembangunan kabupaten Kulonprogo. Komunikasi merupakan hal yang penting dan sangat dibutuhkan untuk mendapatkan partisipasi publik dari masyarakat sebagai pertimbangan bagi pemerintahan. Bentuk media komunikasi yang sederhana dan mudah diakses oleh masyarakat. Bagian dari penciptaan media atau saluran komunikasi yang 
tepat, cepat, murah dan mudah dijangkau. Sehingga tercipta komunikasi timbal balik atau dua arah antara pemerintah dengan masyarakat. Dan tujuan akhir adalah keperluan penanganan dan pengolahan aduan maupun permohonan informasi masyarakat, menjadi bahan dalam pengambilan kebijakan.

PPID menjadi lembaga yang mengkordinasikan pelaksanaan Kpg. Tugas itu sesuai dengan undang-undang nomor 35 tahun 2010 tentang Pedoman Pengelolaan Pelayanan Informasi dan Dokumentasi di Lingkungan Kementrian Dalam Negeri dan Pemerintah Daerah.(Republik Indonesia 2010). Secara internal pemerintah daerah juga menetapkan tim khusus yang mendukung tugas dan wewenang PPID termasuk dalam penyelenggaraan KPg. Komposisi tim ditentukan berdasar Keputusan Bupati Kulon Progo Nomor 215 Tahun 2013 tentang Pembentukan Tim Informasi dan Dokumentasi Pemerintah Kabupaten Kulonprogo.(Kabupaten Kulonprogo 2013)

Gambar 1

Pejabat Pengelola Informasi dan Dokumentasi (PPID)

Kabupaten Kulon Progo

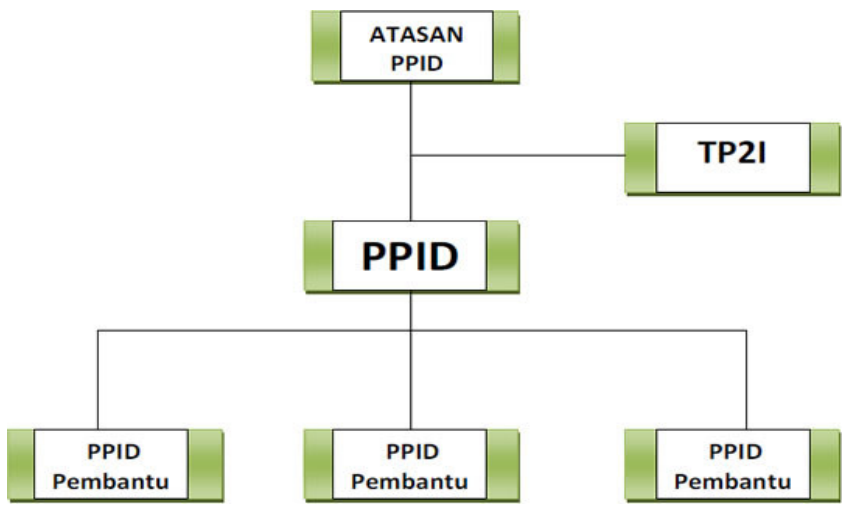

Sumber: http://ppid.kulonprogokab.go.id/pages-56-struktur.html,

Dalam komunikasi dengan masyarakat ternyata Kabupaten Kulonprogo telah menggunakan banyak banyak media.(PPID Kabupaten Kulonporogo 2014, 2015). Kpg hanya salah satunya. Selainnya, warga Kabupaten bisa berkeluh kesah dan melaporkan segala hal yang berkaitan dengan pelaksanaan pemeirntahan dan pembangunan daerah melalui; Siaran RRI Programa 1, setiap hari Jumat jam 07.30.08.00 WIB. Komunikasi juga 
bisa terjadi melalui Meja layanan langsung di Bagian TI Humas Setda Kab. Kulon Progo. Dengan fax bisa menggunakan nomor (0274) 773208, email ppid@kulonprogokab.go.id, Telepon : (0274) 773272, SMS Center : 08112554010. Website juga dibuka melalaui ppid.kulonprogokab.go.id atau www.kulonprogokab.go.id, bahkan semua website dan email resmi SKPD (39 SKPD) dan 12 Kecamatan. Media sosial pun telah dijamah untuk mengakrabkan jajaran pemerintahan dengan rakyat, terutama Facebook dan Twitter.(PPID Kabupaten Kulonprogo 2016).

Gambar 1

Alur Permohonan Informasi Publik di PPID Kabupaten Kulon Progo

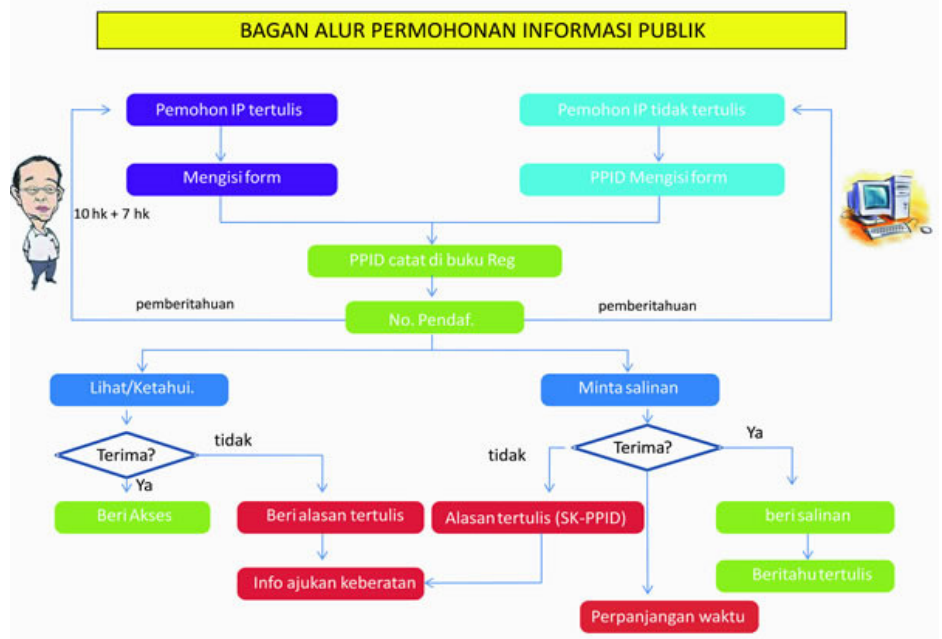

Sumber: http://ppid.kulonprogokab.go.id/pages-59-mekanisme-layanan.html

Dari berbagai media tersebut, Kpg menjadi satu media penghubung lisan yang tak tertulis. Permasalahan publik yang dihadapi oleh masyarakat, yang berkaitan langsung dengan pemerintah maupun tidak, bisa disampaikan langsung selama pelaksanaan. Dalam mencari solusi, pemerintah mungkin tidak langsung menyelesaikan on site, tapi mempertimbangkan terlebih dahulu. Apabila mendapat solusi secara langsung, bisa dilakukan dengan cara musyawarah bersama dengan semua pihak yang hadir. Karena itu, Semua lapisan masyarakat tanpa terkecuali bisa berpartisipasi langsung dalam kegiatan tatap muka publik tersebut. Mereka memiliki yang sama mengajukan pertanyaan, memberikan pertanggapan dan ataupun 
menyodorkan usulan perbaikan maupun pembaruan bahkan memohon bantuan.

Program Kpg di bawah kordinasi PPID Kabupaten Kulon Progo tak mengalami perlakuan yang berbeda pada payung hukumnya. Dasar ini menjadi acuan yang memudahkan pelaksanaan. Fungsi lainnya ialah payung hukum yang melindungi dari penyimpangan-penyimpangan yang tidak diinginkan.

Hukum nasional yang melindungi antara lain; Undang-Undang Republik Indonesia Nomor 14 Tahun 2008 Tentang Keterbukaan Informasi Publik (UUKIP), Peraturan Pemerintah Republik Indonesia Nomor 61 Tahun 2010 Tentang Pelaksanaan Undang-Undang Nomor 14 Tahun 2008 Tentang Keterbukaan Informasi Publik, Peraturan Menteri Dalam Negeri Nomor 35 Tahun 2010 Tentang Pedoman Pengelolaan Pelayanan Informasi Dan Dokumentasi Di Lingkungan Kementerian Dalam Negeri Dan Pemerintahan Daerah, Peraturan Komisi Informasi Nomor 1 Tahun 2010 Tentang Standar Layanan Informasi Publik, Peraturan Komisi Informasi Nomor 2 Tahun 2010 Tentang Prosedur Penyelesaian Sengketa Informasi Publik.

Untuk penguatan teknis pelaksanaan di tingkat daerah Kabupaten Kulonprogo, beberapa hokum peraturan daerah telah melengkapi peraturan perundangan nasional. Peraturan Bupati Kulon Progo Nomor 85 Tahun 2012 Tentang Pedoman Mekanisme Konsultasi Publik Dan Pelayanan Informasi Publik Di Lingkungan Pemerintah Daerah. Penerbitan perda di atas dilengkapi dengan Keputusan Bupati Nomor 215 Tahun 2013 Tentang Pembentukan Tim Pengelola Informasi dan Dokumentasi Pemerintah Kabupaten Kulon Progo.

Dalam Kpg, informasi publik yang dikomunikasikan tidak mencakup secara keseluruhan. informasi yang tertutup itu telah diatur dalam pasal 17 UUKIP.(Republik Indonesia 2008) Jika informasi tersebut yang dibuka dapat berdampak pada hambatan dalam proses penegakan hukum, gangguan terhadap perlindungan hak atas kekayaan intelektual dan persaingan usaha tidak sehat, bahaya dalam pertahanan dan keamanan Negara, resiko 
pengungkapan kekayaan alam Indonesia, serta kerugian dalam kepentingan hubungan luar negeri,

Dengan dasar pasal 3 UU KIP kemudian dapat diketahui bahwa tujuan penetapan keterbukaan informasi publik seperti dalam Kpg dimaksudkan untuk banyak hal.

"Menjamin hak warga negara untuk mengetahui rencana pembuatan kebijakan publik, program kebijakan publik, dan proses pengambilan keputusan publik, serta alasan pengambilan suatu keputusan publik; mendorong partisipasi masyarakat dalam proses pengambilan kebijakan publik; meningkatkan peran aktif masyarakat dalam pengambilan kebijakan publik dan pengelolaan Badan Publik yang baik; mewujudkan penyelenggaraan negara yang baik, yaitu yang transparan, efektif dan efisien, akuntabel serta dapat dipertanggungjawabkan; mengetahui alasan kebijakan publik yang mempengaruhi hajat hidup orang banyak; mengembangkan ilmu pengetahuan dan mencerdaskan kehidupan bangsa; meningkatkan pengelolaan dan pelayanan informasi di lingkungan Badan Publik untuk menghasilkan layanan informasi yang berkualitas" (Republik Indonesia 2008).

Badan Publik harus aktif partisipatif mengikuti aturan dalam UU yang sama. Semua institusi daerah tingkat II, baik eksekutif, legislatif, maupun yudikatif bertugas dalam pengelolaan urusan publik dan kenegaraan yang bersumber dari APBN/D. Selain itu, lembaga Non-Pemerintah yang melaksanakan kegiatan dengan sumber yang sama juga tunduk pada aturan hokum yang sama.

Dalam masyarakat, selain pengertian umum dalam konteks kewarganegaraan, UU KIP juga menambahkan detil tertentu pada Pasal Penjelasan Umumnya. Mereka adalah Pengguna Informasi Publik adalah orang yang menggunakan informasi publik sebagaimana diatur dalam Undang-Undang. Selain itu juga pemohon Informasi Publik, yaitu; "warga negara dan/atau badan hukum Indonesia yang mengajukan permintaan informasi publik sebagaimana diatur dalam Undang-Undang ini”(Republik Indonesia 2008) 
Partisipasi aktif masyarakat dalam persoalan publik dan pemerintahan dalam pelaksanaan KPg juga dikuatkan dengan UU Pelayanan Publik (UUPP). Dalam Bab Umum ada penjelasannya;

"Pelayanan publik adalah kegiatan atau rangkaian kegiatan dalam rangka pemenuhan kebutuhan pelayanan sesuai dengan peraturan perundang- undangan bagi setiap warga negara dan penduduk atas barang, jasa, dan/atau pelayanan administratif yang disediakan oleh penyelenggara pelayanan publik" (Republik Indonesia 2009).

Secara operasional, pelayanan publik yang diberikan kepada masyarakat dapat dibedakan dalam dua kelompok besar yaitu; pertama, pelayanan publik yang diberikan tanpa memperhatikan orang perseorangan, tetapi keperluan masyarakat secara umum yang meliputi penyediaan sarana dan prasarana transportasi, penyediaan pusat-pusat kesehatan, pembangunan lembaga-lembaga pendidikan, pemeliharaan keamanan, dan lain sebagainya; kedua, pelayanan yang diberikan secara orang perseorangan yang meliputi kartu penduduk dan surat-surat lainnya.(Sumaryadi 2010)

Ddalam UUPP juga diatur tentang tiga sektor yang terlibat; Negara, Masyarakat, dan Swasta. Pemerintah harus berupaya keras untuk mewujudkannya, terutama partisipasi masyarakat dalam tiap tahapan kebijakan publik. Hal yang yang sama berlaku dalam layanan lainnya yang diatur dalam Pasal 39 UUPP (Republik Indonesia 2009)

Soetrisno telah memberikan definisi yang berlaku universal tentang partisipasi masyarakat. Kerja sama antara rakyat dan pemerintah dalam merencanakan, melaksanakan, melestarikan dan mengembangkan hasil pembangunan.(Anomsari 2013) Wagle dalam Muhammadiyah mengungkap demokrasi berarti penting saat semua pihak dalam negara, termasuk warga biasa, selalu terlibat dalam proses perumusan dan penyusunan dan penetapan setiap kebijakan publik yang ditetapkan oleh negara. Manfaat nyata yang bisa dirasakan adalah kenaikan tingkat mutu kebijakan publik berpihak pada warga sebagai target kebijakan.(Muhammadiyah 2013)

Keuntungan lainnya adalah masyarakat dapat menyampaikan aspirasinya sekaliigus mengawasi pengambilan kebijakan oleh pemerintahan. 
Muhammadiyah (2013) menguatkan dengan pendapat Moynihan dan Wilcox dalam pembedaan level keterlibatan warga dalam lima kelompok, yaitu: penyampaian keterangan; pemberian konsultasi; penyusunan keputusan bersama; penindakan bersama; dan pendukungan aktivitas.

Tingkat Partisipasi masayarakat dalam peraturan di Indonesia dijelaskan lebih lanjut pada Pasal 41 Peraturan Pemerintah yang melaksanakan UUPP.(Republik Indonesia 2012) Pengikutsertaan masyarakat dalam penyelenggaraan pelayanan publik mencakup keseluruhan proses; penyusunan kebijakan; penyusunan standar; pengawasan dan evaluasi penyelenggaraan; dan pemberian penghargaan. Dorongan dan motivasi partisipasi aktif masyarakat dalam dasar hukum PPID yang demikian dalam program KPg kemudian menjadi bentuk perluasan hak dan kewajiban dari masing-masing pelayan publik dan warganya.

\section{Kamis Paginan Sebagai Media Pelayanan Informasi Publik}

Peserta masyarakat dalam Kpg tiap minggunya sangat beragam dari tahaun ke tahun. Meski masih di wilayah publik, tetapi jangkauan sangat luas menyangkut hubungan antar sektor. PPID memberikan informasi yang telah didokumentasikan.

Tabel 1

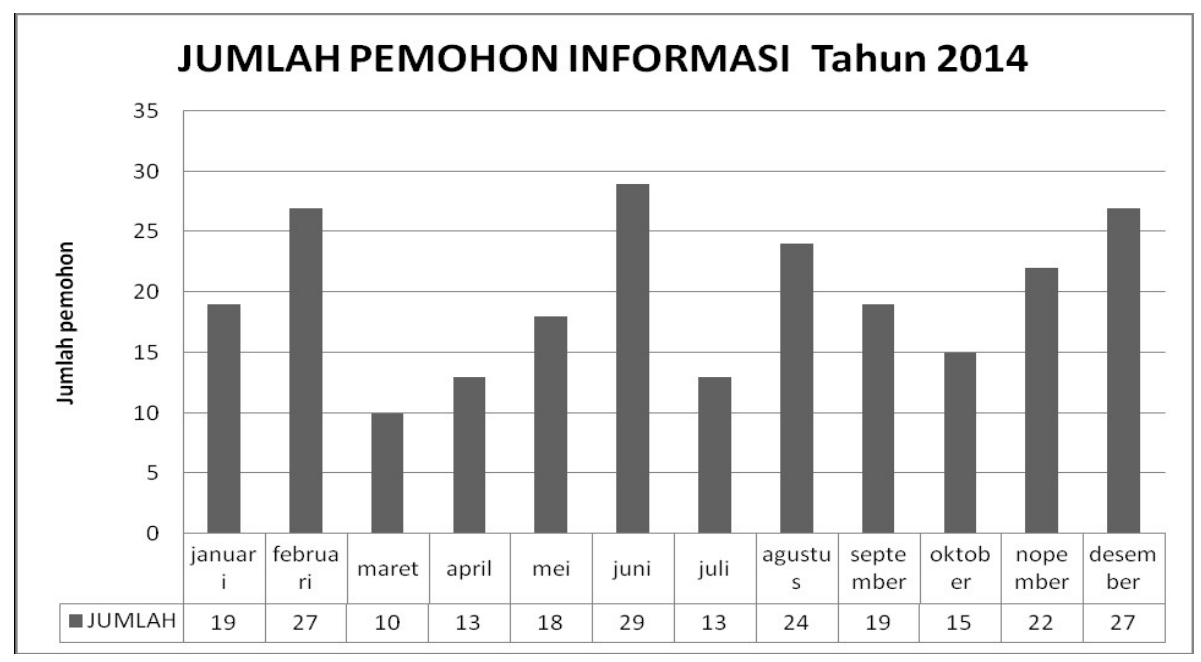

Sumber: laporan PPID Kabupaten Kulonprogo tahun 2014. 
Tabel 2

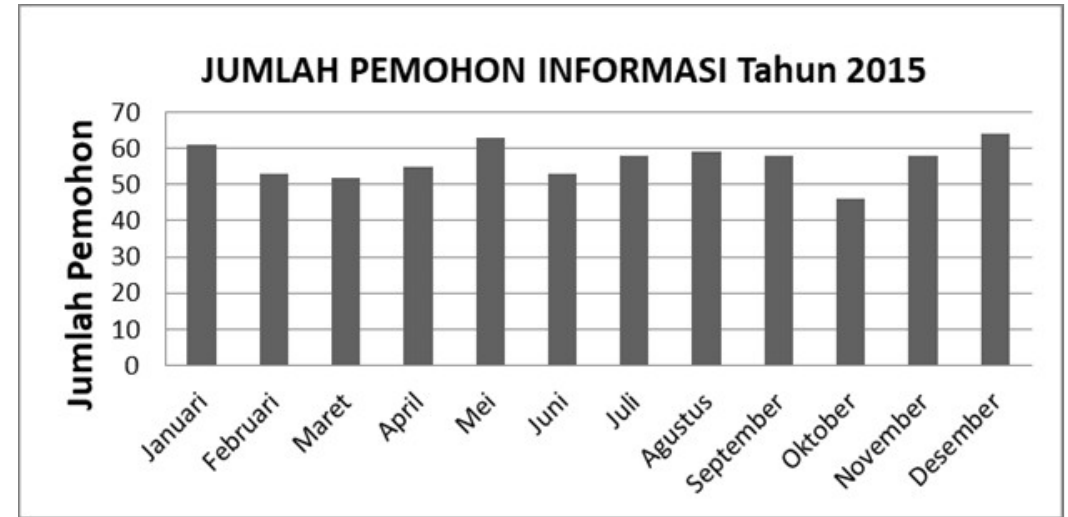

Sumber: laporan PPID Kabupaten Kulonprogo tahun 2015

Tabel 3

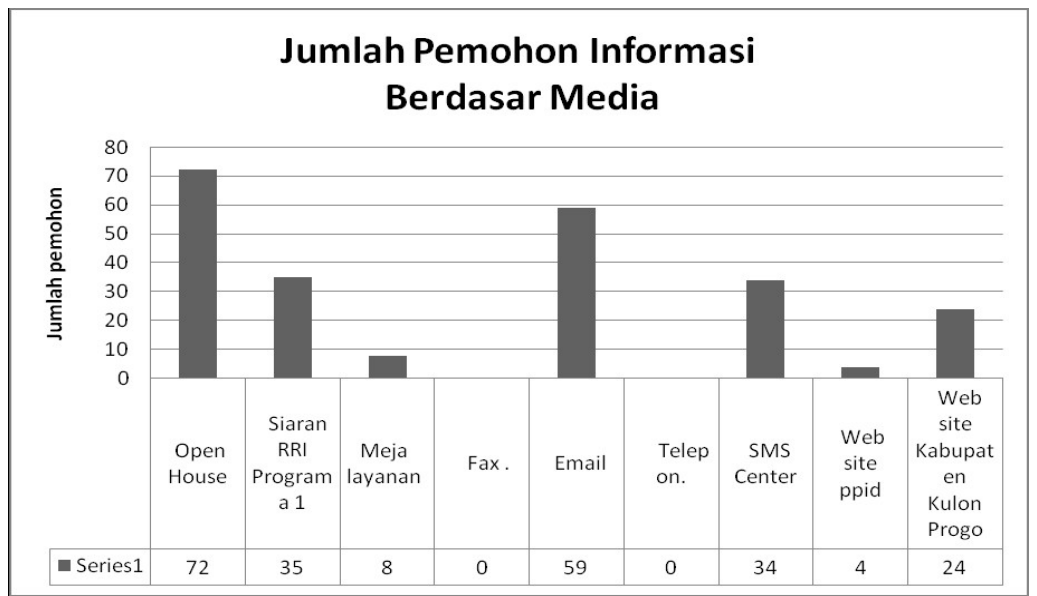

Sumber: laporan PPID Kabupaten Kulonprogo tahun 2014

Tabel 4

JUMLAH PEMOHON INFORMASI BERDASARKAN MEDIA

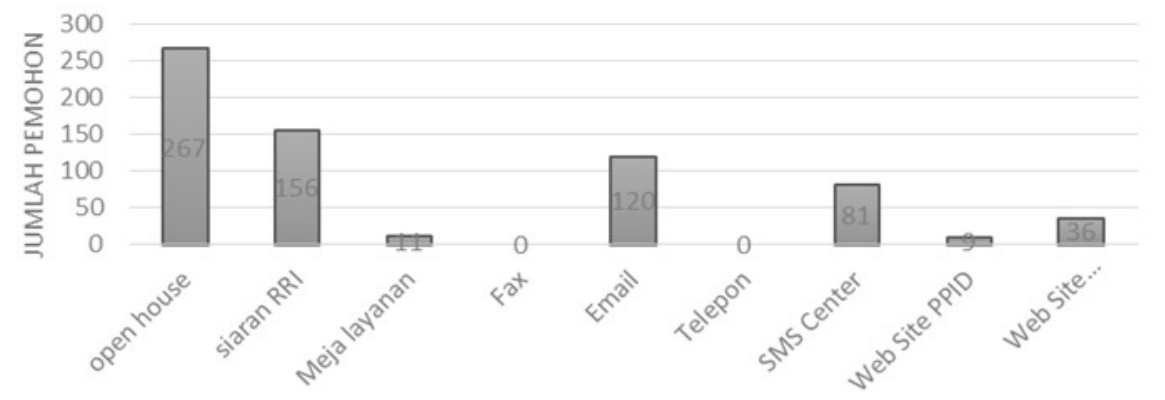

Sumber: laporan PPID Kabupaten Kulonprogo tahun 2015 
Tabel 5

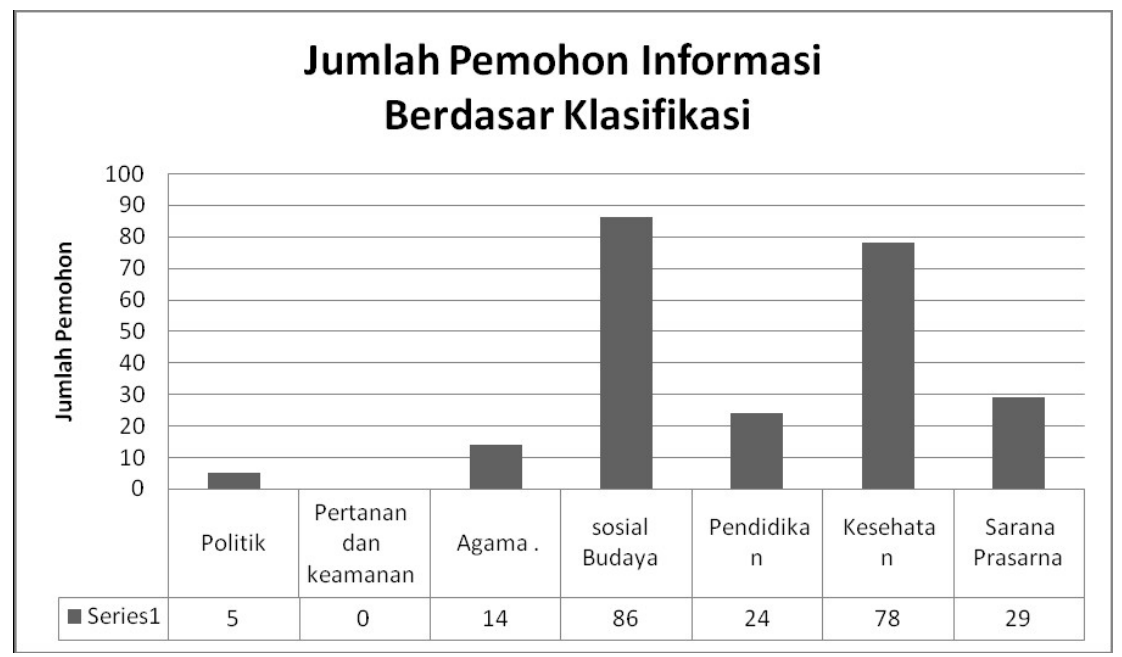

Sumber: laporan PPID Kabupaten Kulonprogo tahun 2014

Tabel 6

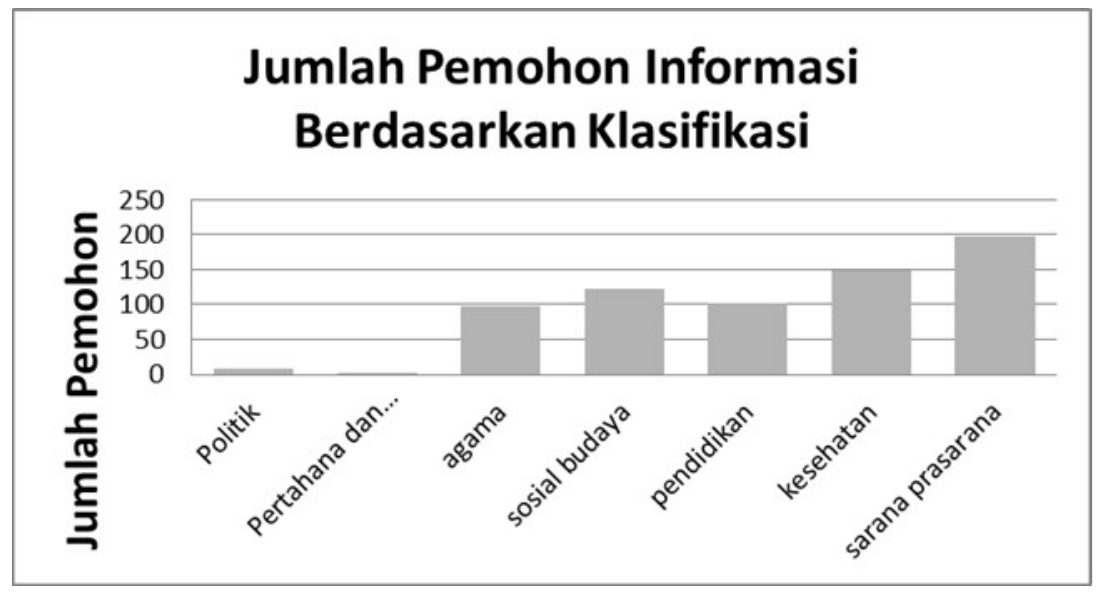

Sumber: laporan PPID Kabupaten Kulonprogo tahun 2014

Bupati Kabupaten Kulon Progo selalu hadir dalam acara silaturahmi tersebut. Ia memang menggangap penting acara ini dalam hubungan layanan pemerintah dan masyarakat. Ia menyatakan, "Saya selalu menyampaikan dalam berbagai forum bahwa pelayanan publik harus mengutamakan logos, etos dan pathos sehingga bisa menyajikan pelayanan prima".

Dengan berbagai persoalan yang dibawa oleh partisipan dari masyarakat dan pihak swasta yang hadir, Pemerintah daerah melalui Bupati pun memberikan tanggapan yang berbeda-beda. Permasalahan yang dibawa akan ditampung terlebih dahulu apabila memerlukan tindakan lanjutan, disposisi, dan rapat dengan Satuan Kerja Perangkat Daerah (yang selanjutnya 
disebut dengan SKPD) maupun lembaga yang menaunginya. Jika permasalahan itu dapat langsung diselesaikan di Kpg, maka langsung ditanggapi oleh bupati maupun stafnya.

Penyelesaian dalam Kpg kemudian bisa dibagi menjadi empat bagian sesuai dengan penjelasan oleh Bupati Kulonprogo. Permasalahan bisa diselesaikan seketika dalam acara Kpg, langsung, diterima untuk diselesaikan di Kpg selanjutnya, atau penyelesaiannya harus dilengkapi dengan disposisi, atau melalui kerapatan secara internal antar aparat pemerintah.

Pada penyelesaian langsung bupati dapat langsung memberikan respon kepada masyarakat yang datang. Permasalahan yang diadukan merupakan kewenangan dari Bupati. Dengan catatan kasus yang diadukan cenderung lebih sederhana tidak memerlukan perencanaan maupun disposisi kepada lembaga lain.

Penyelesaian lanjutan merupakan tindakan yang berkaitan dengan kewenangan Bupati. Respon tidak langsung diberikan, karena perlu berkoordinasi dan klarifikasi dengan pemerintahan di bawahnya. Sehingga dipastikan keadaan di lapangan sesuai dengan yang diadukan dalam Kpg.

Penyelesaian dengan disposisi diperlukan apabila permasalahan yang diadukan di luar kewenangan dari Bupati. Sehingga pemerintah hanya memfasilitasi seperti: mempertemukan kedua belah pihak, mengirimkan surat maupun perwakilan untuk menanyakan kepada lembaga lain. Diharapkan dapat memunculkan solusi yang menjadi jawabannya.

Penyelesaian menggunakan rapat (musyawarah) oleh internal pemerintahan. Bentuknya bisa Musyawarah merupakan salah satu cara penyelesaian dengan mengumpulkan staf ahli. Musyawarah ini dilakukan jika permasalahan yang diadukan, memerlukan perencanaan. Selain itu untuk menyelesaikan perlu pertimbangan dan perencanaan jangka panjang. Juga harus memperhatikan dampak positif dan negatifnya. Sehingga diharapkan ketika dilaksanakan tidak ada yang merasa dirugikan kembali.

Tentang permasalahan yang diadukan oleh sebuah badan usaha. Perusahaan itu mengalami penurunan omset dan juga berakibat pada karyawan yang diliburkan. Hal tersebut disebabkan oleh pemadaman yang 
dilakukan oleh PLN selama 8 hari full, dengan kurun waktu 10.00-16.00 WIB. Perusahaan itu menuntut kepada PLN untuk berkoordinasi sebelum melakukan jadwal pemadaman. Dalam hal ini pemerintah Kulonprogo hanya berwenang disposisi perintah terlebih dahulu. Sebelum memanggil kedua pihak untuk berkoordinasi, dengan kata lain sebagai penengah.

Sesuai dengan pernyataan yang diberikan oleh staf ahli pemerintah Kulonprogo. Bahwa sebagian dari peserta Kpg yang belum puas atas jawaban atau tindakan yang dilakukan. Maka pada kamis selanjutnya akan mendatangi kembali sebagai klarifikasi dari permasalahan yang diadukan. Kemudian ada tipe peserta yang akan mengadukan apabila bupati dan wakilnya berada di pendopo.

Penyelesaian yang berjenjang tersebut tidak bisa dipisahkan dari sejauh mana tingkat partisipasi masyarakat. Wilcox telah menunjukkan tingkat keterlibatan warga yang dipengaruhi oleh Arstein dimana warga Negara adalah pengontrol aktivitas pemerintahan (Muhammadiyah 2013).

Tabel 7

Delapan Tangga Partisipasi

\begin{tabular}{|c|c|}
\hline 1. Kontrol oleh warga Negara & \multirow{3}{*}{$\begin{array}{c}\text { Masyarakat } \\
\text { punya } \\
\text { kewenangan } \\
\text { penuh / } \\
\text { Partisipasi Penuh }\end{array}$} \\
\hline 2. Pendelegasian wewenang & \\
\hline 3. Kemitraan & \\
\hline 4. Konsesi & \multirow{3}{*}{$\begin{array}{l}\text { Partisipasi } \\
\text { Simbolik }\end{array}$} \\
\hline 5. Konsultasi & \\
\hline 6. Pemberian Informasi & \\
\hline 7. Terapi & \multirow{2}{*}{$\begin{array}{l}\text { Tidak Ada } \\
\text { Partisipasi }\end{array}$} \\
\hline 8. Manipulasi & \\
\hline
\end{tabular}

Dengan pandangan tersebut bisa dikemukakan bahwa Kpg telah berhasil memberikan kesadaran partisipasi masyarakat dalam permasalahan publik secara langsung. Mereka mendapatkan informasi yang sepatutnya dari pihak-pihak yang berwenang sehingga memberikan kepuasan secara langsung selain bisa menyampaikan informasi berkaitan permasalahan publik yang dihadapi. Komunikasi antara pihak yang berkepentingan dan berwenang akan bermanfaat juga dirasakan pada saat pemilihan umum, yaitu antara para 
calon peserta pemilu dan masyarakat pemilih seperti yang ditemukan oleh Zana (2014). Namun hasil positif dari komunikasi langsung secara tatap muka seperti Kpg yang bermanfaat bagi semua pihak tidak bisa ditemukan dalam forum komunikasi karena tidak bisa mendatangkan pihak pimpinan yang berwenang dalam pengambilan keputusan sehingga forum yang dibangun tidak bisa menjaring partisipasi masyarakat secara optimal. (Anomsari 2013)

\section{Kesimpulan dan Saran}

Kpg adalah media penghubung oral tak tertulis yang menghendaki keterlibatan masyarakat dalam kontrol kebijakan publik. Semua lapisan masyarakat bisa menyampaikan permasalahan publik kepada pemimpin daerah tingkat II Kabupaten Kulon Progo dengan bertatap muka secara langsung. Penyelesaian dalam pelayan publik dalam Kpg dibagi menjadi empat Permasalahan bisa diselesaikan seketika dalam acara Kpg, langsung, diterima untuk diselesaikan di Kpg selanjutnya, atau penyelesaiannya harus dilengkapi dengan disposisi, atau melalui kerapatan secara internal antar aparat pemerintah. Peningkatan sosialisasi Kpg dalam komunikasi kerja tatap muka antar pimpinan pemerintah daerah Kabupaten Kulonprogo dan warganya agar keterlibatan semua lapisan masyarakat tidak terbatas. Kpg merupakan jaring aspirasi paling disukai oleh warga, maka kerja sama antar lembaga pemberintah dan pemerintah yang terkait dengan permasalahan publik bisa dikuatkan.

\section{Daftar Pustaka}

Anomsari, Endah Tri. 2013. "Partisipasi Masyarakat Dalam Pengelolaan Hutan Bersama Masyarakat (Studi Kasus Di Kecamatan Karanggayam, Kebumen)." Jurnal Natapraja 1(1).

Atmadja, Iin Suny. 2017. "Peranan Pemerintah Desa Dalam Sistem Administrasi (Studi Di Desa Sariharjo Kecamatan Ngaglik Kabupaten Sleman)." Lensa Hukum 6.

Kabupaten Kulonprogo. 2013. Keputusan Bupati Kulon Progo Nomor 215 Tahun 2013 tentang Pembentukan Tim Informasi dan Dokumentasi Pemerintah Kabupaten Kulonprogo.

Muhammadiyah. 2013. "Partisipasi Publik Sebagai Strategi Mewujudkan Good Governance Otonomi Daerah." Jurnal Ilmu Pemerintahan Otoritas 3(1):57-66.

Nashir, Fatah. 2017. "Kamis Paginan Sebagai Media Pelayanan Publik 
Bupati Kulonprogo Hasto Wardoyodalam Perspektif Siyasah." UIN Sunan Kalijaga, Yogyakarta.

PPID Kabupaten Kulonporogo. 2014. laporan PPID Kabupaten Kulonprogo tahun 2014. Kulonprogo.

PPID Kabupaten Kulonporogo. 2015. laporan PPID Kabupaten Kulonprogo tahun 2015. Kulonprogo.

PPID Kabupaten Kulonprogo. 2016. "Profil PPID." Diambil (http://ppid.kulonprogokab.go.id/pages-128-profil-ppid.html).

Republik Indonesia. 2008. Undang-Undang Republik Indonesia Nomor 14 Tahun 2008 Tentang Keterbukaan Informasi Publik.

Republik Indonesia. 2009. Undang-Undang RI Nomor 25 Tahun 2009. Tentang. Pelayanan Publik.

Republik Indonesia. 2010. Undang-undang RI nomor 35 tahun 2010 tentang Pedoman Pengelolaan Pelayanan Informasi dan Dokumentasi di Lingkungan Kementrian Dalam Negeri dan Pemerintah Daerah.

Republik Indonesia. 2012. Peraturan Pemerintah RI No. 96 Tahun 2012 tentang Pelaksanaan Undang-Undang Nomor 25 Tahun 2009 Tentang Pelayanan Publik.

Sitoresmi, Suci. 2013. "Efektivitas Sistem Informasi Layanan Aspirasi dan Pengaduan Online Rakyat (LAPOR!) Pada Unit Kerja Presiden Bidang Pengawasan dan Pengendalian Pembangunan (UKP4)." Universitas Indonesia.

Sumaryadi, I. Nyoman. 2010. Sosiologi Pemerintahan.Dari Prespektif Pelayanan, Pemberdayaan, Interaksi Dan System Kepemimpanan Pemerintahan Indonesia. Jakarta: Ghalia Indonesia.

Triantaka, Gusti Made, dan Ni Made Ari Yuliartini Griadhi. 2015. "Pengaduan Masyarakat Sebagai Bentuk Partisipasi Dan Peningkatan Pelayanan Publik Untuk Mewujudkan Pemerintahan Yang Baik." EJournal Kertha Negara 3(2).

Zana, Iqbal Saputra. 2014. "Partisipasi Politik Masyarakat Dalam Pemilihan Umum Kepala Daerah Kalimantan Timur Tahun 2013 Di Kelurahan Sempaja Utara Kecamatan Samarinda Utara." eJoumal Administrasi Negara 3(2):837-47. 
Bawa Supratman, Fatah Nashir, A.S. Rahman, Zainul Arifin, Cipto Sembodo 